\title{
Impact of integrated pest management on the population of leafminers, fruit borers, and natural enemies in tomato
}

\author{
Impacto do manejo integrado de pragas sobre populações de minadores de folhas, \\ broqueadores de frutos e inimigos naturais na cultura do tomateiro \\ Moacyr Mascarenhas Motta Miranda ${ }^{1}$ Marcelo Coutinho Picanço ${ }^{2}$ \\ José Cola Zanuncio ${ }^{3}$ Leandro Bacci ${ }^{4}$ Ézio Marques da Silva ${ }^{5}$
}

\section{- NOTA -}

\section{ABSTRACT}

The objective of this work was to evaluate the impact of integrated pest management (IPM) in the productivity of the tomato and in the populations of leafminers, fruit borers, and natural enemies in tomato crops. The treatments were calendar (spraying twice weekly with insecticides and fungicides), IPM (spraying when action thresholds were achieved), and control (no pesticide was applied). IPM was the most efficient system of pest control due to presenting similar productivity and $65.6 \%$ less pesticide applications than in the calendar. The attack of Tuta absoluta (Meyrick) (Lepidoptera: Gelechiidae) and Liriomyza spp. (Diptera: Agromyzidae) to the leaves only achieved the action threshold in the final phase of the cultivation. The main fruit borer was Neoleucinoides elegantalis (Guen.) (Lepidoptera: Crambidae), followed by T. absoluta and Spodoptera eridania (Cr.) (Lepidoptera: Noctuidae). The natural enemy populations were severely reduced by excessive pesticide applications. Predators were more abundant than parasitoids. The most abundant predators were Araneidae, Anthicus sp. (Coleoptera: Anthicidae), Cycloneda sanguinea larva (L.) (Coleoptera: Coccinellidae), Staphylinidae adults (Coleoptera), Orius sp. and Xylocoris sp. (Hemiptera: Anthocoridae), Formicidae (Hymenoptera), and Phlaeothripidae (Thysanoptera). The most abundant parasitoids were Hymenoptera of the families Eulophidae, Braconidae (Bracon sp. and Chelonus sp.), Trichogrammatidae [Trichogramma pretiosum (Riley)] and
Bethylidae (Goniozus nigrifemur Ashmead), besides Tachinidae (Diptera).

Key words: Lycopersicon esculentun, Neoleucinoides elegantalis, predators, parasitoids, action thresholds.

\section{RESUMO}

O objetivo deste trabalho foi avaliar o impacto do manejo integrado de pragas (MIP) na produtividade e populações de minadores de folhas, broqueadores de frutos, predadores e parasitóides na cultura de tomate. Os tratamentos foram calendário (pulverizações de inseticidas $e$ fungicidas duas vezes/semana), MIP (pulverizações de inseticidas somente quando os niveis de controle foram atingidos) e testemunha (sem aplicação de inseticidas e fungicidas). O tomateiro no MIP apresentou produtividade semelhante à do calendário com redução de 65,6\% das pulverizações de inseticidas. O ataque de Tuta absoluta (Meyrick) (Lepidoptera: Gelechiidae) e Liriomyza spp. (Diptera: Agromyzidae) às folhas só atingiu o nível de controle na fase final do cultivo. $O$ principal broqueador de frutos foi Neoleucinoides elegantalis (Guen.) (Lepidoptera: Crambidae), seguido de T. absoluta e Spodoptera eridania (Cr.) (Lepidoptera: Noctuidae). As populações de inimigos

${ }^{1}$ Engenheiro Agrônomo, Mestre, Departamento de Biologia Animal (DBA), Universidade Federal de Viçosa (UFV). 36571-000, Viçosa, MG. ${ }^{2}$ Engenheiro Agrônomo, Professor Adjunto, Doutor, DBA, UFV, E-mail: picanco@ufv.br. Autor para correspondência.

${ }^{3}$ Engenheiro Florestal, Professor Titular, Doutor, DBA, UFV.

${ }^{4}$ Engenheiro Agrônomo, doutorando do programa de pós-graduação em Fitotecnia.

${ }^{5}$ Engenheiro Agrônomo, DBA, UFV. 
naturais foram grandemente reduzidas pelas aplicações excessivas de inseticidas. Os predadores foram mais abundantes que os parasitóides. Os predadores mais abundantes foram: Araneidae, Anthicus sp. (Coleoptera: Anthicidae), larvas de Cycloneda sanguinea (L.) (Coleoptera: Coccinellidae), adultos de Staphylinidae (Coleoptera), Orius sp. e Xylocoris sp. (Hemiptera: Anthocoridae), Formicidae (Hymenoptera) e Phlaeothripidae (Thysanoptera). Os parasitóides mais abundantes foram Hymenoptera das famílias Eulophidae, Braconidae (Bracon sp. e Chelonus sp.), Trichogrammatidae [Trichogramma pretiosum (Riley)] e Bethylidae (Goniozus nigrifemur Ashmead), além de Diptera: Tachinidae.

Palavras-chave: Lycopersicon esculentum, Neoleucinoides elegantalis, predadores, parasitóides, níveis de controle.

Tomato fields present a large number of pests. The leafminers and fruit borers are the most important ones (LOPES FILHO, 1990; PICANÇO et al., 2000). In the first group, the major species in South America are Tuta absoluta (Meyrick) (Lepidoptera: Gelechiidae) and Liriomyza spp. (Diptera: Agromyzidae). In the northeast of Minas Gerais State, Brazil, these species cause damage from September to March and from April to August, respectively. T. absoluta initially damages stalks of tomatoes and can kill tomato plants at their earlier development stages. After fruiting, fruit borers become more important, especially T. absoluta, Neoleucinoides elegantalis (Guen.) (Lepidoptera: Crambidae), and Helicoverpa zea (Bod.) (Lepidoptera: Noctuidae) (PICANÇO et al., 2000). Natural enemies are found in larger populations in non-sprayed tomato fields (MIRANDA et al., 1998b), where they can reach populations four times bigger than in sprayed fields (PACORA, 1982). Thus, these natural enemies may play an important role in controlling tomato pests and they need to be preserved by growers.

Due to high cost of implantation of tomato culture, the vast majority of growers use chemical pesticides intensively aiming to maintain their production. About 120 insecticides and 90 fungicides are registered in Brazil to control the pests and diseases in tomato. Abamectin is among the insecticides most used in the tomato crops. This insecticide is used in the mites, leafminers, and fruit borers in the tomato crops. Chlorothalonil and maneb are among the fungicides more used in the control of tomato diseases. Chlorothalonil is used in the control of Alternaria solani, Colletotrichum gloeosporioides, Phytophthora capsici, Phytophthora infestans, Septoria lycopersici, and Stemphylium solani in the tomato crops. Yet maneb is used in the control of $\boldsymbol{P}$. infestans in the tomato crops (ANDREI, 1999).
This is done since characteristics such as format, weight and lack of spots on fruit are important for higher prices of tomatoes. For these reasons, tomato fields are usually sprayed up to three times a week with insecticides and fungicides. In this context, Integrated Pest Management (IPM), represents a proposal of rationalization of chemical pesticide use in tomato fields, aimed at a reduction. Successes of IPM reaching $90 \%$ reduction of pesticide applications with similar production as that of sprayed fields have been reported (TRUMBLE \& ALVARADORODRIGUEZ, 1993). The sampling of the tomato leafminers and fruit borers is made by the evaluation of the percentages of mined leaves and of fruits bored, respectively. The action thresholds in the tomato IPM for leafminers and fruit borers are 20 and $5 \%$ of attack. (PICANÇO et al., 2000). In these cases, the producers would achieve lower production costs with lower level of labor and environment contamination, besides preserving natural enemies of tomato pests. Thus, the objective of this work was to evaluate the impact of IPM on predation, number of pesticide applications, control of leafminers and fruit borers, and natural enemies in tomato fields.

This research was conducted from January 30 to May 22, 1996, at the Federal University of Viçosa, Viçosa, Minas Gerais State, Brazil, in a tomato field of the Santa Clara variety. The treatments were: calendar (spraying twice weekly with fungicides and insecticides), IPM (spraying when action thresholds were achieved), and control (no pesticide was applied). Action thresholds in the IPM were $20 \%$ of leaves mined and $5 \%$ of fruits bored. The used fungicides were chlorothalonil 750 WP (Daconil BR ${ }^{\circledR}$ ) and maneb 640 WP $\left(\right.$ Curzate $\mathrm{M}+$ Zinco $\left.^{\circledR}\right)$ in the doses of 1.8 and $1.75 \mathrm{~kg}$ $\mathrm{ha}^{-1}$, respectively. The insecticide used was abamectin $18 \mathrm{EC}$ (Vertimec $18 \mathrm{CE}^{\circledR}$ ) in the dose of $1.0 \mathrm{~L} \mathrm{ha}^{-1}$ (ANDREI, 1999).

The experimental design was in randomized blocks with four replicates. Each replicate was represented by eight rows with 13 plants in a $1 \times 0.5 \mathrm{~m}$ spacing, with two and four meters in its side. Effect of the treatments was evaluated in the 24 central plants located in the six inner rows. Cultivation practices were those normally used in tomato fields (FILGUEIRA, 2000). Sampling was achieved twice a week in 10 plants per replicate. Predators and parasitoids were sampled by beat of the plant apex on plastic tray (MIRANDA et al., 1998b). Leafminers were evaluated in the third or fourth leaves from the top of tomato plants and stalk mining was also evaluated (MIRANDA et al., 1998b). Fruit borers were evaluated in the first group of completely formal fruit from the apex of the plants (MIRANDA et al., 1998b). 
Alter fruit ripened and fruit bored were evaluated once a week during harvesting. Commercial fruits were those larger than $4 \mathrm{~cm}$ in diameter. Data of production and number of insecticide application were submitted to the variance analyses and these averages compared by Tukey test at $5 \%$ of probability error.

Tomato plants cultivated under the calendar and IPM systems presented similar production, with 28 and 30ton ha- ${ }^{-1}$ respectively, while a decrease of $73 \%$ in production was found in the control, with the production of only 7.7 ton $\mathrm{ha}^{-1}$. The number of insecticide applications was $65.6 \%$ lower with the IPM system ( 8.5 applications) than with the calendar system (25 applications). Thus, the pests were efficiently controlled with IPM at lower costs. Sprayings carried out on the IPM targeted mainly fruit borers. The periods of occurrence of these pests were the critical for the crop requiring almost as many insecticide applications as in the calendar system. Only in the final stage of tomato production the insecticide applications targeted the leafminers.

Considering sampling in 40 plants twice a week and a salary of US $\$ 100$ per person, the labor cost for sampling on the IPM system is US\$ 7.14month ${ }^{-1}$ ha $^{-1}$ (PICANÇO et al., 2000). Lower number of sprayings in the IPM than in the calendar system, saved US\$ $1249.50 \mathrm{ha}^{-1}$, with a net value of US\$ 1242.36 saved in the IPM system which is equivalent to 311 boxes of tomato with $6 \mathrm{~cm}$ in diameter, at a value of US\$ 4.00 per box. For this reason, to achieve higher profits compared to IPM, a tomato producer needs to get 36.2ton ha ${ }^{-1}$ instead of 28ton $\mathrm{ha}^{-1}$ corresponding to an increase of $22 \%$ on productivity, which would be, technically, very difficult. Besides this, lower use of equipments such as sprayers would contribute to a longer longevity of them, contributing to a greater economy. Natural enemy numbers were only slightly higher in the IPM system, probably due to the still necessary pesticide applications made (Figure 1A). Due to an increase in the fruit borer population (Figure 1B), the number of insecticide applications was similar to that of the calendar system. Highest populations of natural enemies were found in place with no pesticide applications (Figure 1A). Lower populations of predators and parasitoids were found during the final stage of tomato cycle in the IPM and calendar systems. A total of 20.5 and 28 predators per 100 plants and 13 and 16 parasitoids per 100 plants, were found on plants under the calendar and IPM systems, respectively. In the control treatment, a total of 19.5 parasitoids per 100 plants was found, being similar to the predator population until about half of the cultivation period. Predators showed a pronounced increase in population during the final part of this period, reaching 108 predators per 100 plants (Figure 1A).

T. absoluta and Liriomyza spp. showed numbers above action threshold at the end of this experiment (Figure 1C). These pests established themselves slowly, possibly due to the fact that tomatoes have not been planted in this area for last three years. Liriomyza spp. were more common during the winter, from May to August. Both pests showed a tendency for population increases during the crop cycle, but very little damage was observed in the upper part of the tomato plants. Fruit borer populations were similar in all treatments and always above the damage level. Due to lack of spraying in the control, the production period of this treatment was shorter than in the other ones.

The most abundant predators were Araneidae, Anthicus sp. (Coleoptera: Anthicidae), Cycloneda sanguinea larva (L.) (Coleoptera: Coccinellidae), Staphylinidae (Coleoptera) adults, Orius sp. and Xylocoris sp. (Hemiptera: Anthocoridae), Formicidae (Hymenoptera), and Phlaeothripidae (Thysanoptera). These insects were considered key predators in tomato plants, especially against eggs and first instar Lepidoptera (MIRANDA et al., 1998a and b). The most abundant parasitoids were wasps from the families Eulophidae and Braconidae, presented at similar levels in all treatments, followed by Trichogrammatidae, Bethylidae, and Tachinidae flies, which were more abundant in the control. The populations of Eulophidae and Braconidae remained constant during all of the cultivation period, while Trichogrammatidae and Bethylidae showed higher populations levels at the end of the crop cycle and the Tachinidae flies presented population peaks around the middle of the tomato cycle.

T. absoluta larvae were parasitized by Bracon sp., Chelonus sp. (Braconidae) and Goniozus nigrifemur Ashmead (Bethylidae) while the egg parasitoids of this pest were mainly the Trichogrammatidae. Establishment of Bethylidae and Trichogrammatidae were dependent on pest density but this last group became established at very low densities of eggs of T. absoluta showing higher ability to find them (PENA \& WADDILL, 1983).

The fruit borer species were T. absoluta, $N$. elegantalis, and Spodoptera eridania (Figure 1B). In all treatments $\boldsymbol{N}$. elegantalis was the most abundant, being responsible for 64,70 , and $79 \%$ of fruit damage on calendar, IPM and, control treatments, respectively, with decreasing numbers in the calendar and IPM over time. T. absoluta and S. eridania showed similar populations in the IPM and calendar systems, except 


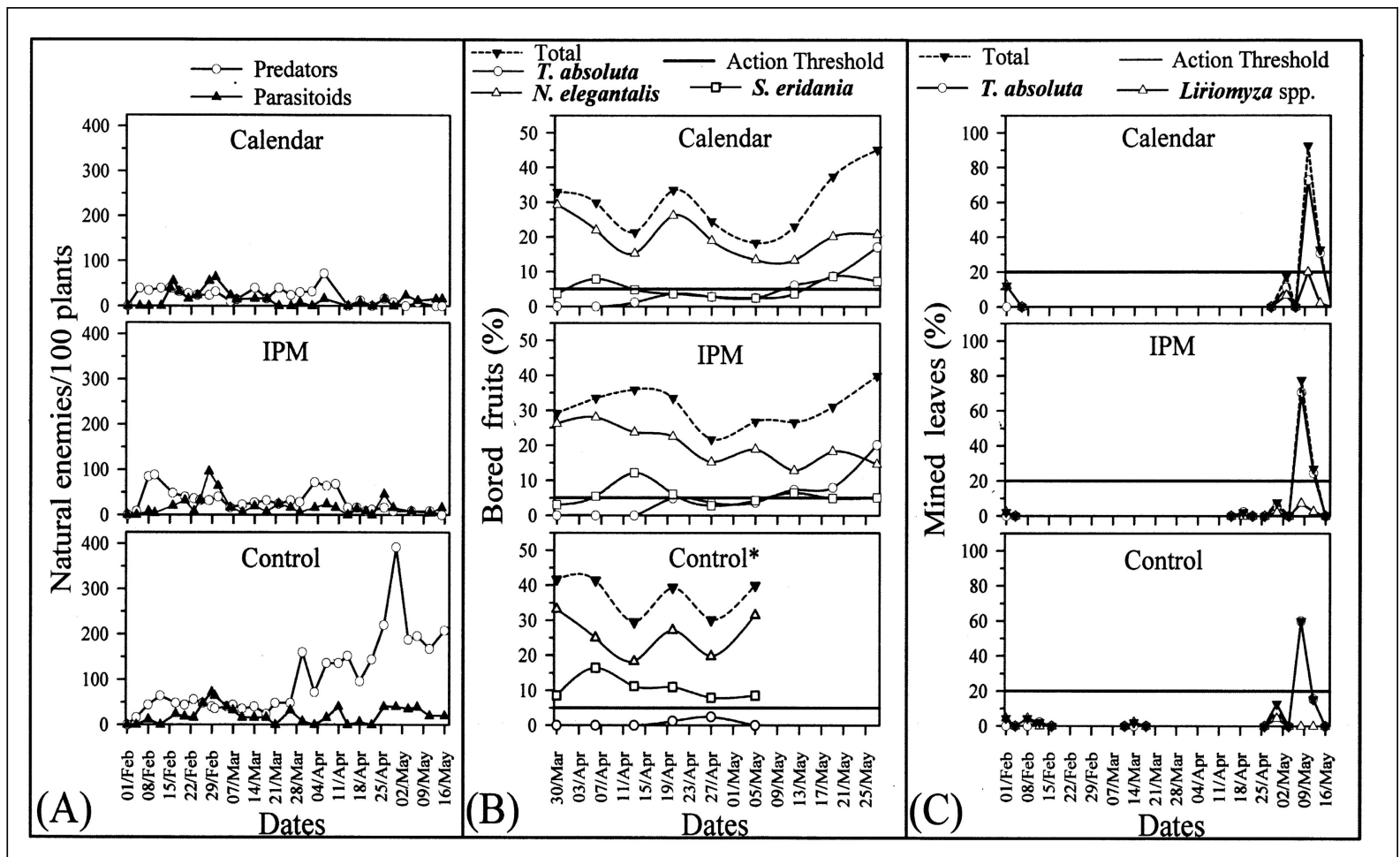

Figure 1 - (A) Number of predators and parasitoids on tomato plants in three pest control systems. (B) Percentage of tomato bored fruit by Tuta absoluta, Neoleucinodes elegantalis and Spodoptera eridania in three pest control systems. (C) Attack intensity of leafminers in tomato plants in three systems of pest control. Viçosa, Minas Gerais State, Brazil. 1996. (*Fruiting period ended due to fungi diseases).

during early stages of the production period (when only $\boldsymbol{S}$. eridania was found) and at the end of the harvesting period (when $\boldsymbol{T}$. absoluta presented higher population than $S$. eridania). The incidence of $\boldsymbol{T}$. absoluta increased, gradually, during the test, while $\boldsymbol{S}$. eridania showed stable populations. Attacks of $\boldsymbol{S}$. eridania to the fruit in the control treatment was higher than that of $\boldsymbol{T}$. absoluta, but when attack of this last pest occurred, the production period of tomato plants in this treatment was finishing.

S. eridania is seldom reported as an important borer of tomato fruits in the literature (CATIE, 1990). On the east of Minas Gerais State, Brazil this species has been very common in tomato fields, being nowadays, the main tomato fruitworm species in this region. The tomato fruit borers more frequently reported are a complex of Lepidoptera: Noctuidae polyphagous such as $\boldsymbol{H}$. zea (LOPES FILHO, 1990; TRUMBLE \& ALVARADO-RODRIGUEZ, 1993), Pseudoplusia oo (Cr.) (LOPES FILHO, 1990), Spodoptera exigua (Hüb.), and Heliothis virescens (Fabr.) (TRUMBLE \& ALVARADO-RODRIGUEZ, 1993).

Losses by $\boldsymbol{N}$. elegantalis was due to the deficiency of chemical control against this pest. Recent studies show that caterpillars of this species hatch mainly during the first two hours of light when they bore into the fruit. For this reason chemical control would be efficient only during this period when caterpillars migrate and bore into the fruit. Since this pest only leaves the fruit for pupation, its individuals are protected against insecticide applications during almost all of their immature stage. One possibility to overcome this problem is to use insecticides with high penetration capacity.

The methodology for evaluation of $N$. elegantalis was not efficient because the exit holes were observed instead of the entrance holes. The assessment based on the exit holes is not helpful in preventing the major damage by the insect (CASSINO et al., 1995). On the other hand sampling of entrance holes will allow the early detection of the attack by this pest favoring the use of more efficient control measures. Also, due to the behavior of this pest, natural biological control of larvae is not very efficient reaching only $2 \%$ (PLAZA et al., 1992), which leads to higher level of fruit bored in the control than in the other treatments. Finally, spraying has been carried out around 9am with abamectin which is not very efficient against this pest in the area of study. 
In conclusion, the IPM was more efficient with a similar production and $65.6 \%$ less pesticide applications than in the calendar. The most important pest in the IPM was $N$. elegantalis. Fruit production period was the most critical phase of the crop, requiring similar number of spraying both in the IPM and in the calendar system. Natural enemy populations were severely reduced by pesticide applications and were also dependent on pest numbers. Predators were more abundant than parasitoids.

\section{ACKNOWLEDGMENTS}

Acknowledgments to Prof. Ricardo A. Zucchi (ESALQ/USP) by identification of the Thrichogramma, to Prof. Celso Oliveira de Azevedo (UFES) by identification of the Bethylidae, to Profa. Angélica Maria Penteado-Dias (UFSCAR) by identification of the Braconidae, Sr. Ayr M. Bello from Rio de Janeiro, Rio de Janeiro State, Brazil by identification of the Coleoptera, and Prof. Paulo Sérgio Fiuza Ferreira (UFV) by identification of the Hemiptera.

\section{REFERENCES}

ANDREI, E. Compêndio de defensivos agrícolas. 6.ed. São Paulo : Andrei, 1999. 676p.

CASSINO, P.R. et al. Proposta metodológica de monitoramento de pragas em tomateiro estaqueado. Anais da Sociedade Entomológica do Brasil, v.24, n.2, p.279$285,1995$.

CENTRO AGRONOMICO TROPICAL DE INVESTIGAÇÃO E ENSEÑANZA (CATIE). Guia para el manejo integrado de plagas del cultivo do tomate. Turrialba : Editorama, 1990. $138 \mathrm{p}$.
FILGUEIRA, F.A.R. Novo manual de olericultura agrotecnologia moderna na produção e comercialização de hortaliças. Viçosa : UFV, 2000. 402p.

LOPES FILHO, F. Tomate industrial no submédio São Francisco e as pragas que limitam sua produção. Pesquisa Agropecuária Brasileira, v.25, n.2, p.283-288, 1990.

MIRANDA, M.M.M. et al. Ecological life table of Tuta absoluta (Meyrick) (Lepidoptera: Gelechiidae). Biocontrol Science and Technology, v.8, n.4, p.597-606, 1998a.

MIRANDA, M.M.M. et al. Sampling and non-action levels for predators and parasitoids of virus vectors and leaf miners of tomato plants in Brazil. Mededelingen Faculteit Landbouwwetenschappe Universiteit Gent, v.63, n.2b, p.519-523, 1998 b.

PACORA, R.J.F. Parasitismo observado sobre dos insectos plaga en el cultivo de la papa del Valle Chillón. Revista Peruana de Entomologia, v.21, n.1, p.125, 1982.

PENA, J.E.; WADDILL, V. Larval and egg parasitism of Keiferia lycopersicella (Walsingham) (Lepidoptera: Gelechiidae) in southern Florida tomato fields. Environmental Entomology, v.12, n.5, p.1322-1326, 1983.

PICANÇO, M.C. et al. Manejo integrado de pragas de hortaliças. In: ZAMBOLIM L. (Ed). Manejo integrado de doenças, pragas e ervas daninhas. Viçosa: UFV, 2000. Cap.8, p.275-324.

PLAZA, A.S. et al. Biología, hábitos y enemigos naturales del Neoleucinoides elegantalis (Guenée). Revista Colombiana de Entomologia, v.18, n.1, p.32-37, 1992.

TRUMBLE, J.T.; ALVARADO-RODRIGUEZ, B. Development and economic evaluation of an IPM program for fresh market tomato production in Mexico. Agriculture, Ecosystems and Environment, v.43, n.3/4, p.267-284, 1993. 